\title{
Lexis
}

Journal in English Lexicology

9| 2015

Utterer-Centered Studies on Lexical Issues

\section{About Plural Morphology and Game Animals: from Old English to Present-Day English}

\section{Fabienne Toupin}

\section{(2) OpenEdition \\ 1 Journals}

\section{Electronic version}

URL: http://journals.openedition.org/lexis/964

DOI: $10.4000 /$ lexis.964

ISSN: 1951-6215

\section{Publisher}

Université Jean Moulin - Lyon 3

\section{Electronic reference}

Fabienne Toupin, «About Plural Morphology and Game Animals: from Old English to Present-Day English », Lexis [Online], 9 | 2015, Online since 13 May 2015, connection on 10 December 2020. URL : http://journals.openedition.org/lexis/964; DOI : https://doi.org/10.4000/lexis.964

Lexis is licensed under a Creative Commons Attribution-NonCommercial-NoDerivatives 4.0 International License. 


\title{
About Plural Morphology and Game Animals: from Old English to Present-Day English
}

Fabienne Toupin ${ }^{1}$

\begin{abstract}
My focus here will be on those animal names which never (e.g. deer) or occasionally (e.g. herring) take the $-s$ suffix in the plural in Present-Day English. After a detailed presentation of these names $(\S 1)$, I will try to show $(\S 2)$ that they form a lexical category in Guiraud's sense, that is, a non-arbitrary set of nouns with common features at the level both of the signified and of the signifier, and constituting, from a diachronic perspective, a matrix having enabled membership of the category to develop until today. I will then try to explain why this category resisted analogical extension of the $-s$ plural marker, by bringing in the culture of Anglo-Saxon England and the very special status of a group of animals in the culture in question (§3). My conclusion (§4) will stress that multicausality is at work in that resistance to analogy, the cultural factor put forward in $\S 3$ being the main explanation. I will eventually explain how these animal names fit into the traditional description of English nouns, and then into Culioli's speaker-centered theory, known as the Théorie des Opérations Prédicatives et Enonciatives.
\end{abstract}

Key words: animal names - number - plural morphology - analogy - regularisation lexical category - speaker-centered theories - English - Anglo-Saxon England

$* * *$

\section{Résumé}

Je m'intéresse ici aux noms d'animaux qui ne prennent jamais (ex. deer) ou parfois seulement (ex. herring) le suffixe $-s$ du pluriel en anglais contemporain. Après avoir présenté ces noms de manière détaillée $(\S 1)$, j'essaierai de montrer $(\S 2)$ qu'ils forment une catégorie lexicale au sens de Guiraud, c'est-à-dire un ensemble non arbitraire de noms ayant des propriétés communes au niveau du signifiant et du signifié et qui, du point de vue diachronique, fonctionne comme une matrice. Ceci a permis l'accroissement de la catégorie jusqu'à aujourd'hui. Mon objectif sera ensuite d'expliquer pourquoi cette catégorie de noms d'animaux a résisté à l'extension analogique du $-s$ du pluriel, en faisant appel à la culture de l'Angleterre anglo-saxonne (§3). Je conclurai en soulignant que plusieurs facteurs sont en cause dans cette résistance à l'analogie, l'explication formulée dans le §3 étant la principale. J'indiquerai enfin quelle place ces noms d'animaux occupent dans la description traditionnelle des noms anglais et développerai deux liens avec la théorie énonciative de Culioli, connue sous le nom de Théorie des Opérations Prédicatives et Enonciatives.

\footnotetext{
Laboratoire Ligérien de Linguistique, UMR 7270, Université François-Rabelais de Tours: fabienne.toupin@univ-tours.fr
} 
Mots-clés : noms d'animaux - nombre - morphologie du pluriel - analogie régularisation - catégorie lexicale - linguistique de l'énonciation - anglais - Angleterre anglo-saxonne 


\section{Introduction ${ }^{2}$}

This title is an implied reference to Bolinger's 1992 paper "About furniture and birds", to which Wierzbicka replied the same year. That one's paper should be discussed and replied to is probably one's highest expectation in any field of scientific enquiry, and it is mine here.

My focus in the next pages will be on those animal names which never (e.g. deer) or occasionally (e.g. herring) take the $-s$ suffix in the plural in Present-Day English (PDE). ${ }^{3}$ After a detailed presentation of these names $(\S 1)$, I will try to show $(\$ 2)$ that they form a lexical category in Pierre Guiraud's sense, that is, a non-arbitrary set of nouns with common features at the level both of the signified and of the signifier, and constituting, from a diachronic perspective, a matrix enabling membership of the category to develop in PDE. I will then try to explain why this category resisted analogical extension of the $-s$ plural marker, by bringing in the culture of Anglo-Saxon England (§3). My conclusion (§4) will stress that multicausality is at work in that resistance to analogy. I will try to explain how these animal names fit into the traditional description of English nouns, and then into Culioli's speaker-centered theory, known as the Théorie des Opérations Prédicatives et Enonciatives.

Support for my claims will be primarily linguistic, but essential information will also be derived from archeological, anthropological and art history sources; this will eventually lead me to advocate, with other scholars, the construction of an object for speaker-centered theories that would not be separated from the material world of which it is part.

My corpus includes examples taken from the Oxford English Dictionary (OED). The way their source is presented in the OED has been kept, thus making them easily identifiable (see ex. (1) for instance). The other examples are taken from various $20^{\text {th }}$ and $21^{\text {st }}$ c. sources, whose list is to be found at the end of the bibliography.

An introduction to Culioli's theory is available in English, viz. Bouscaren et al. [1992]. Nothing concerning the present subject will be found in that book, nor in others written by enunciation linguists (e.g. Adamczewski \& Delmas [1982]). How the animal world is conceptualized by speakers and represented by languages, and animal names in particular, is a fascinating field of research, but so far in the social sciences only etymologists and folkbiologists [cf. Berlin 1992] have taken an interest in it. The French school of enunciation linguistics, when dealing with nouns in English, has been heavily biased towards the study of determination, and plural morphology seems to be the poor relation of the noun phrase. By contrast, plural morphology in nouns is well studied in Wakelin [1977: 109-111], surveying the different English dialects; much is said concerning the -en inflection and the so-called double plurals, but nothing concerning "zero plurals" or the absence of $-s$ in the plural, which I take as evidence that, in that respect, there exists no significant difference between standard English and the dialectal varieties.

\footnotetext{
${ }^{2}$ I am very grateful to Professor Jean-Marc Gachelin (p.c.) who took a friendly interest in this paper. My knowledgeable colleague reminded me of a number of relevant elements that have been taken into account here.

3 The names of all languages are abbreviated according to the common conventions in contemporary English scholarship; a complete list of the abbreviations is provided after the bibliography.
} 


\section{Zero-plural animal names in Modern and Present-Day English}

\subsection{Definition of zero-plurals}

In order to delineate my field of enquiry, I will start with some very basic considerations. Some of the following may therefore seem to be labouring the obvious. Morphosyntactically, animal names are nouns, a significant number of which can switch between count and uncount use. They are treated as uncount when they refer to material (leather, fur, etc.):

(1) One volume in old sheep, the other in calf. (1911, Tregaskis' Catal Bks. $\left.N^{\circ} 70853\right)$

or to food:

(2) He went looking for pheasant because he was hungry. (LDCE: xxxii)

Examples (1)-(2) illustrate a rule of English according to which animal names are treated as uncount nouns, i.e. morphologically invariable nouns. They cannot be plural and as such fall outside the scope of the present paper.

When treated as count nouns, the bulk of animal names behave regularly with respect to the marking of plural, i.e. they take the $-s$ inflection characteristic of PDE:

(3) a-She was seen one day sitting on a roof and talking to some sparrows who were just out of her reach. (Animal Farm: 29)

$b-^{*}$...talking to some sparrow who were...

Yet a subset of names conform to a different pattern. They can be found with no final $-s$ in the plural, the latter being then morphologically identical with the singular form:

(4) a-Bulls which had always been tractable suddenly turned savage, sheep broke down hedges and devoured the clover, cows kicked the pail over, hunters refused their fences and shot their riders on to the other side. (Animal Farm: 36) $b$ - *...sheeps broke down hedges...

(5) Biting flies and other insects can be a major problem for Caribou in certain areas. [...] Chief predators are humans and wolves, although Grizzly Bears, Wolverines, Lynx and golden eagles may take a few Caribou, particularly the young. (NAM: 845)

(6) In the 19th century, many Elk were primarily plains animals and were shot by ranchers to reduce grazing competition with domestic livestock. (NAM: 829)

(7) $a$ - In the 15 th century, millions of American Bison grazed from the Atlantic Ocean almost to the Pacific and from Mexico and Florida into Canada. (NAM: 853) $b-. .$. millions of American bisons grazed ...

Taking here a structuralist position, I will consider that not taking the $-s$ plural inflection is tantamount to taking a $\emptyset$ plural inflection, and that we are dealing here with a twomember microsystem \{regular -s / more exceptional $\varnothing$ \}. There is also good ground in the history of English for arguing for a $\varnothing$ plural inflection (see §2). PDE count nouns that occasionally (e.g. bison) or always (e.g. sheep) take the $\emptyset$ plural inflection I shall call "zero plurals" in this paper. 


\subsection{Zero-plural animal names as compared with the other zero plurals ${ }^{4}$}

Zero plurals include lexemes other than animal names. Retaining the expressions used by Quirk et al. [1985: 308-309], I will briefly list them here, not going into detail as to their quite complicated morphological behaviour (for which I refer to Quirk et al. as quoted):

- some "nationality nouns", mainly those ending in -ese (e.g. the Vietnamese);

- some "quantitative nouns" (viz. dozen, hundred, thousand and million, but also less common and semantically specialized brace, gross, head, hundredweight, yoke, etc.), a handful of measures (e.g. horsepower, hertz, ...), of units of weight (stone) or currency units (e.g. quid (British English slang), yen, ...);

- eventually, some zero plurals have base forms ending in [s] or [z], thus raising a morphological problem of interpretation which causes native speakers to hesitate between singular or plural treatment. This is the subcategory of "nouns with equivocal number", no matter whether the final phonetic segment is historically a genuine marker of plural (as in dice [dars]) or not (as in species ['spi:fi:z]). Such zero-plural nationality nouns as Swiss [swis] or Vietnamese [vi,etnə'mi:z] are also to be included here.

Zero plurals other than animal names are rather marginal in PDE. Numerically marginal, because the nationality nouns concerned are not likely to number more than 10 , the quantitative nouns do not represent more than 16-odd items, and about 17 nouns with equivocal number are involved. Morphosyntactically marginal, if we focus on the quantitative nouns, because their special morphological behaviour is observable only under specific syntactic conditions.

By contrast, zero-plural animal names (henceforth ZP animal names) probably amount to more than 80 (see appendix).

8 names in that total are "nouns of equivocal number", their base form ending in [s] or [z], viz. grouse, hippopotamus, luce, lynx, moose, plaice, rhinoceros and walrus. ${ }^{5}$ But the following note, found in the OED s.v. grouse - a noun of disputed origin, whose earliest instances date from the mid-16 ${ }^{\text {th }} \mathrm{c}$. - indicates that in this matter it is also necessary to take the history of individual words into consideration: "It is uncertain whether the $16^{\text {th }}$ c. form is a sing [ular] (used collect[ively]) or the plural of *grow."

In languages displaying a morphological distinction between singular and plural, speakers have been known to evolve spurious singulars to match forms misinterpreted as plural. This is especially true of loan-words, because their foreign character further confuses morphological analysis. I would like to illustrate this with the noun rhinoceros:

(8) And sa pai willid in-to a wod was full of wild bestis, Rynoceros, as I rede, pe romance pam callis. (a1400-50, Alexander 4133)

(9) A beast all barred ouer with small plates somewhat like to Renocero. (1596, RALEIGH Discov. Gviana 61)

\footnotetext{
${ }^{4}$ All the figures given here and in the subsequent paragraphs are open to revision. Extra words might well be added to the list of ZP animal names when further research is carried out. (I have for instance a list of 70odd items referring of animals found only on the American continent, e.g. opossum, that still needs checking.) Others might have to be crossed out, such as horse, whose plural form horse is still current, but dialectally only.

${ }^{5}$ I temporarily leave out horse, which does end in [s] but is of native origin unlike the other words in the list.
} 
(10) The forests are full of Rhinocero's. (1680, MORDEN Geog. Rect., Ganges Penins. 412)

(11) Rhinoceroses of the size of a large dog. (1753, HANWAY Trav. I. vii. xcv. 440)

(12) The remains of elephants and rhinoceri accompanied by marine vegetables. (1799, KIRWAN Geol. Ess. 68)

Rhinoceros was borrowed by English from late Latin (rhinoceros) and its earliest recorded instances go back to the $14^{\text {th }} \mathrm{c}$. Over a time span of 400 years, 3 different plural forms showed up - with what looks like a $\emptyset$ inflection in (8), with a regular -s inflection in (10) and (11), and eventually with a Latin plural inflection $-i$ in (12). Example (9) illustrates the process of backformation just mentioned, whereby the singular *renocero/rhinocero was formed; (10), which postdates (9) by a century, displays the same spurious singular form, and the apostrophe may show uneasiness over the adequacy of adding a native ${ }^{6}$ plural inflection $(-s)$ to a foreign base.

I don't think it is any accident if the 8 names considered here are all evolved from non-native nouns with a word-final sibilant:

- $\quad$ grouse is of unknown origin for the OED, but according to Onions, could be referred either to a medieval Latin word or to a Welsh one;

- $\quad$ hippopotamus was borrowed twice, once from OF (ypotame) but the modern form is due to a later adoption from late Latin (hippopotamus);

- $\quad$ luce comes from OF lus, luis;

- lynx is from late Latin lynx;

- $\quad$ moose comes from native American Narragansett (moos);

- $\quad$ plaice is another word of French origin: OF plaïz/plaïs/plaiis;

- $\quad$ walrus is a Dutch loan-word (walrus/walros).

Two other names have to be added to the list, namely crayfish and partridge. Their PDE base forms do not end with [s] or [z] but their original forms did (original referring to the form of the word when first borrowed by English). Both words come from OF (respectively OF crevice and perdriz/pertriz). In the case of crayfish, a misinterpretation of the word crevice as a compound of fish, under the influence of Southern ME where the second syllable was confounded with vish, "fish », must also have been instrumental in making the name a zero plural, fish being itself such a noun.

My next remarks have to do with syntax. When treated as count nouns, no specific syntactic conditions are required for ZP animal names not to take the $-s$ inflection, if they can take it at all. But some contexts seem to favour an $-s$ suffix, others a $\emptyset$ inflection.

\subsection{Contexts that seem to favour an $-s$ inflection}

Examples (13) and (14) have syntactically parallel constructions, viz. walrus is the semantic head of the subject NP, and is preceded by a quantifying expression. Yet, the noun behaves differently with respect to the marking of plural:

(13) The last remnant of walrus did not leave us until the temperature had sunk below zero. (1856, KANE Arctic Expl. I. xiii. 140)

(14) A number of Pacific Walruses do not migrate northward, instead passing the summer on Round Island in Bristol Bay, Alaska. (NAM: 725)

\footnotetext{
${ }^{6}$ Native is used in this paper to refer to the Anglo-Saxon origin of words or morphemes; non-native applies to words or morphemes which are not reflexes of Old English forms.
} 
140 years or so separate (13) from (14) but it is possible to find strictly contemporaneous examples (below, late $20^{\text {th }}$-c. ones):

(15) In the enlarged countryside, wildlife bred freely. Hares multiplied; deer and boar were released into the woods from game farms; the urban ox returned to a healthier diet of bloodied, pulsing flesh. (England, England; here boar = wild boar)

(16) Russian Wild Boars were released in 1910 and 1912 on a North Carolina preserve near the Tennessee border. (NAM: 818)

Observation of my corpus tends to show a difference in morphological behaviour of the nouns premodified by an adjective (Pacific in (14), Russian in (16)), whose role is to denote specific taxa. In other words, reference to species rather than generic taxa would tend to favour an -s inflection. I haven't been able to identify other contexts or criteria with the same effect.

\subsection{Contexts that seem to favour a $\emptyset$ inflection}

Animal names do not add -s but $\emptyset$ when premodifed by such expressions as a flock of, a herd of, etc.:

(17) A couey of Partridge. (1579, E. K. Gloss. Spenser's Sheph. Cal. Apr. 118) Comp.: I sende yowe by this bringer half a dossen partterigs ... I sende owte my hawke this day to kyll yowe parterige for super on Monday. (a1550, in Ellis Orig. Lett. Ser. III. III. 71)

(18) Shoals of maycril. (1789, MRS. PIOZZI Journ. France I. 2)

(19) I have often seen flocks of snipe crossing the bay. (1845, COULTER Adv. in Pacific iii. 29)

Comp.: The Calcutta market is well supplied with snipes. (1827, JOHNSON Ind. Field Sports 36)

(20) A herd of fourteen reindeer was seen. The horns of the entire band - for the hinds carry them as well as the stags - were still in velvet. (1908, Blackw. Mag. July 105/2)

This case is clearly different from absence of variation in number, implying use of the determiner $\emptyset$, which is the case when two or more nouns are coordinated, and more especially when coordination is reinforced by such a correlative as both ... and or neither ... nor [Quirk et al. 1985: 280]:

(21) They could discover in them [the woods] neither Elephant nor Buffalo. (1731, MEDLEY Kolben's Cape G. Hope I. 79)

This syntactic device, whose effect is to balance one noun against another one of contrasting meaning (retour à la notion in the current French terminology), is attested in my corpus as early as the ME period:

(22) His fadir slow bath schep and net. (a1300, Cursor Mundi 3019)

I have repeatedly observed that subject position favoured this tendency: 
(23) The frost is so hard that woodcock and mallard are driven from inland copses and marshes to the open springs. (1894, SKELTON Table-t. Shirley 64)

but other syntactic positions are found, such as object in (24) or prepositional complement in (25):

(24) The pond will moreouer keepe Shote, Seale, Trought, and Sammon, in seasonable plight, but not in their wonted reddish graine. (1602, CAREW Cornwall II. 105b)

(25) In woodcock and true snipe the ear appears below and not behind the eye. (1872, COUES N. Amer. Birds 249)

Sometimes thorny cases turn up. While there can be no doubt that the nouns in bold type in (26) display absence of variation in number due to coordination, (27) could illustrate absence of variation too or, equally probably, use of the $\varnothing$ plural suffix:

(26) My days here are most enjoyably spent in identifying species of bird and mammal and fish and reptile and insect - almost none of which is well known to me. (POM: 439)

(27) Wildlife may be spotted throughout the Poudre Canyon. Bear, mountain lion, elk and deer are found at all elevations. (FC: 27)

Apart from a handful of exceptions the exact list of which remains to be drawn (nouns like cod, deer and sheep), ZP animal names can always take the regular $-s$ plural inflection. In other words, zero plural in these nouns is an option that speakers can go for, not a rule.

\subsection{Zero-plural animal names: lists}

\subsubsection{The core list}

Quirk et al. [1985: 307-8] provide a useful list of animal names in the form of a morphological continuum. It is reproduced below, with a shortened list in (i):

(i) Regular plural, e.g.:

cow, eagle, monkey, etc.

(ii) Usually regular plural:

elk, crab, duck (zero only with the wild bird)

(iii) Both regular and zero plurals:

antelope, reindeer, fish, flounder, herring, shrimp, woodcock

(iv) Usually zero plural:

bison, grouse, quail, salmon, swine

(v) Always zero plural:

sheep, deer, $\operatorname{cod}^{7}$

Subsets (ii) to (v) yield a core list of $18 \mathrm{ZP}$ animal names. Apart from morphological behaviour with respect to the marking of plural, certain features appear to be shared by most of the 18 items and must somehow be relevant:

\footnotetext{
7 These 3 nouns do have an attested -s plural in MnE (as late as in 1890 for sheep, for instance) but not in
} PDE. 
- $\quad$ They are common gender nouns; duck certainly can refer to a female fowl whose male is the drake, but its primary sense, according to the OED, is « a swimming bird of the genus Anas ».

- 9 of them (i.e. half of the total) are PDE reflexes of OE words: crab, deer, duck, elk, fish, herring, sheep, swine and woodcock. 3 other names deserve attention: reindeer (which comes from ON), shrimp (which is obscurely related to MHG, MLG and ON), and $\operatorname{cod}$ (a word of uncertain origin but known only in English). If cod-fish means "bag-fish », as some have conjectured from the appearance of the fish, then it is definitely of $\mathrm{OE}$ origin. So all in all 12 names out of the 18 in the core list are of Germanic origin, and this is too high a proportion (approx. 67\%) to be mere accident.

- $\quad$ Apart from sheep and swine, the animals in question represent:

- fowl (duck, grouse, quail, woodcock);

- fishes (cod, flounder, herring, salmon..., fish being the name of the class), or shellfish (crab, shrimp);

- cervids (elk, reindeer..., deer referring to the whole family), or other ruminant mammals of the ox family (antelope, bison) somehow felt to be close to deer, as is clear in the definition of antelope given by the OED: « the popular and literary name for the numerous species of the deer-like ruminant genus Antilope ».

The corresponding animal names are found in combinations of the crab-fishing, duckhunting or woodcock-shooting type; sometimes verbal nouns are formed from the name, like shrimping "catching shrimps »; such compounds as herring-season and quail-time designate culturally established divisions of the year, when the animals are killed in accordance with set hunting or fishing rules. In view of such lexical observations, the word game seems relevant to describe these animals, although game is normally restricted to " wild animals or birds such as are pursued, caught or killed in the chase » (OED s.v. game). Throughout this paper I will then use game to refer to animals that are either hunted, fished or shot.

Sheep and swine not being game animals, it is only natural that sheep and swine should occur in different combinations, of the sheep-breeding or swine-dealing type, and that there should exist no such thing as *sheep- or swine-season.

Game is usually cooked and eaten, so all the animals in question, whether fish, flesh or fowl, are articles of food, and some of them (e.g. the woodcock) are even greatly valued as such. Sheep and swine, domesticated for centuries for their flesh (among other things) share this edible quality.

\subsubsection{The extended list}

Of the last two features just mentioned, one regards the signifier (its Germanic origin, including $\mathrm{OE}$ ), the other the signified (game animals). Taking these features as criteria for eliciting further material, ${ }^{8}$ I have established an extended list of ZP animal names, first by looking at PDE reflexes of OE animal names (very valuable OE lists being available in Barnaud [2001], Roberts et al. [2000], and Sauer [1999]), and then by looking up the names of well-known game animals in dictionaries of PDE. Other names were incorporated into the list on a more accidental basis: these turned up with a $\emptyset$

\footnotetext{
8 The gender feature is not taken into consideration here because most animal names are common gender nouns (this criterion is therefore irrelevant).
} 
plural suffix in examples I was collecting concerning other animal names. I retained all the names for which evidence of zero plural can be found in the PDE corpus.

The result is a list of 85 lexemes, appended to this text. On top of these there are 5 names (crocodile, giraffe, hare, pidgeon, swordfish), of which I could find no PDE occurrence with a $\varnothing$ plural inflection, but which are to be added to the list on account of their being labelled as "Wn1" or "Wn2" by the Longman Dictionary of Contemporary English:

[Wn1] = nouns that usually change (add -s) in the plural, but sometimes (as with animals when talking about hunting) have a plural that is the same as the singular.

Examples: There were three pheasants for sale.

He went looking for pheasant because he was hungry.

[Wn2] = nouns that usually or often do not change (add -s) in the plural but can do so (as when talking about different kinds of animal, esp. fish, with the same name, or about insects or other small animals which cause disease or damage).

Examples: He caught five salmon. [LDCE: xxxii]

The Atlantic and Pacific salmons are closely related.

The extended list does not add subcategories to those put forward by Quirk et al. (cf. §.1.5.1); the extra 67 animal names simply fall into subcategories (ii) to (v), thus providing each description ("usually regular plural", etc.) with a more comprehensive list of examples. Yet, the list as a whole is by no means exhaustive, and there are several reasons for this. First, I have come across serious methodological problems that preclude at the moment any possibility of exhaustiveness; I list the main ones in the appendix, inserting my own provisional answers. Then, making such an inventory is a full-time job in itself, if it is feasible at all, which I begin to doubt in view of the methodological difficulties. At some point I had to somewhat arbitrarily stop looking for further items to include in the list.

The proportion of items of Germanic origin in the extended list is not significantly altered in comparison with the core list (more than 1 noun in 2 are reflexes of Germanic words), and all the names, irrespective of their origin, are semantically distributed as follows:

- 2 names (greenfly and hookworm) stand out from the rest as designating insects that cause disease or damage;

- 2 names (horse and neat/neten) refer to domestic animals and therefore belong with sheep and swine found in the core list;

- all the other names are those of birds, fish or mammals which are game animals with various degrees of typicalness for a speaker of British English (see §1.5.1 for the kind of lexical evidence on which assessment of "gameness" is based). If for instance snipe, shell-fish, pike and trout pose no particular problem:

(28) The delighted pointer would dash forward to the well-known 'bottoms' in eager expectancy of ducks and snipe. (1842, LOVER Handy Andy 1)

(29) Pike and trout are to be had in the lochs. (1875, MCILWRAITH Guide Wigtownshire 24)

(30) A happy hunting-ground for shell-fish gatherers. (1896, LAMB Ann. Ayrshire Parish i. 21)

Other animals can be considered game in an Asian context (e.g. tiger) or in an African one: 
(31) a- He shot several lion. (LDCE: xxxii)

b- Plenty of gazelles, wild boars, and lions for the chase. (1851, LAYARD Pop. Acc. Discov. Nineveh xiii 352)

or again in a North American context:

(32) Elk once ranged through most of what is now the U.S. and southern Canada, but their number dwindled as settlements and farming took over their habitats and also as a result of hunting, both for the market and for subsistence. (NAM: 829)

\section{From the list to the lexical category}

Synchronically, the nouns examined here share some features, both from a semantic point of view (the concept in common being "game animal") and from a morphological one (they are zero plurals). Linguistic appearances therefore seem to be telling of a lexical category in Guiraud's sense, that is, a set of words displaying common features in terms both of the signifier and of the signified:

Il est possible, comme le veut la sémantique structurale, qu'il y ait, en français, un système de la spatialité qui oppose «haut» / «bas», «long» / 《large», « horizontal » / « vertical », etc., mais il s'agit d'un système logique et non lexical car ces oppositions ne sont pas manifestées sur le plan de la forme signifiante. [...]

Sous le nom de catégorie étymologique ou lexicale - les deux notions se confondent [...], le système fonctionnant à la fois en synchronie et en diachronie -, on entend ici l'ensemble des mots qui présentent des caractères sémiques (signifiés) et morphologiques (signifiants) communs. [Guiraud 1986: 20]

But how can the lexical category in question be accounted for? How has it evolved so far? Does it tend to expand or to retract? This analysis cannot be complete unless it now integrates the diachronic dimension into the picture.

For anyone with a knowledge of the history of English, the most obvious way of accounting for ZP animal names in PDE is to argue for grammatical inheritance from OE. OE nouns inflected for plural in several different ways, zero plural being one of them. So, basically, the argument would be that the plural form of swine in PDE is swine because OE swin took the $<\varnothing>$ plural suffix ${ }^{9}$ that ox takes $<-$ en $>$ (oxen) from $\mathrm{OE}<-$-an $>$, that hawk takes <-s> (hawks) from $\mathrm{OE}<-a s>$, or again that goose signals plural number with vowel alternation (geese) because in OE mutated plural was already the rule for this word.

Mossé [1945: 66] mentions 4 OE animal names that inflected for plural by taking the $<\emptyset>$ suffix, among a broader category of neuter nouns:

- deor « wild beast » > PDE deer

- hors « horse » > PDE horse

- neat « an ox or a cow, cattle, beast, animal » > PDE neat (now archaic or regional, while the alternative form neten is obsolete)

- swin « pig» > PDE swine

But investigation based on Barnaud [2001], Roberts et al. [2000], Bosworth \& Toller [1954], Hall \& Meritt [1960] has elicited other neuter nouns to be added to the list:

\footnotetext{
${ }^{9}$ Here plural suffix is short for nominative and accusative plural suffix.
} 
- floc « flounder, fluke » > PDE fluke

- sceap « sheep » > PDE sheep

- weorf « young ass » > PDE -

- wicg « steed » > PDE widge (dial. or obs.)

The following could be included too, despite much lexicographical hesitation or contradiction as to their exact gender:

- ac-weorn « squirrel » > MnE aquerne (obs.)

- facg/fagc « plaice, loach » > PDE -

- fifel « sea-monster» > PDE -

- fugel-timber « young bird» > PDE -

- sceadd « shad» > PDE shad

- scric/screc « thrush» > PDE shrike

- truht « trout» > PDE trout.

Yet I think any explanation of ZP animal names in PDE in terms of grammatical inheritance from OE is flawed. First because such names as OE bar (PDE bear) or fisc (PDE fish) used to inflect like stan, i.e. taking the <-as> plural suffix, but are attested as early as ME as zero-plurals:

(33) Ech man is efned to pe deore pe he nimeð after geres [...] sum bere, sum leun. (c1200, Trin. Coll. Hom. 211)

(34) Foghul and fiche, grett thing and small. (a1300 Cursor Mundi (Cott.) 9395)

Then, the main flaw in that explanation is that it does not say why these animal names resisted analogical extension of the $-s$ plural marker among English nouns. Analogical extension, or regularisation, is "the generalisation of a morpheme or relation which already exists in the language into new situations or forms" [McMahon 1994: 71]. In the course of the ME period, the stan pattern attracted all the other patterns to itself, and the original variety of inflections was eventually reduced to the suffix $\langle-s /-e s\rangle$, from $\mathrm{OE}<-a s>$ (for details see McMahon [1994: 71-73]). Such was the influence of the analogical process that numerous nouns were regularized, very few plural forms today bearing testimony to $\mathrm{OE}<-a n>$ (cf. oxen) or to the $\mathrm{OE}$ mutated plural (cf. geese, mice, lice). In the face of such sweeping change, not only did ZP animal names stand their ground (i.e. resist regularisation), but in time they also came to constitute a fully-fledged category attracting newcomers to English (Italian, Congolese, Narragansett, ... loanwords).

It is true that analogy, unlike sound change with which it is often contrasted, is seldom regular and exceptionless. But to explain away ZP animal names as a "residue of irregular forms" - having resisted one of the most powerful analogical changes in the history of English ever - would not be much of a conclusion.

It should be clear by now that if the theory of direct inheritance from $\mathrm{OE}$ has to be discarded, it is as a gross simplification that does not account for the category of ZP animal names developing by going against the historical tide (increasing from some 15 items in $\mathrm{OE}$ to more than 80 nowadays). It is time to move from diachrony to history: Guiraud's concept of lexical category is part of his theory concerning the structure of the French lexicon, which itself reflects a particular stance on lexical change (best illustrated in the author's well-known study of the names for the cat and for the young wild boar in 
Contemporary French). In this stance internal and external causes of change complement one another:

Il y a donc un double déterminisme dans lequel, loin de s'exclure, les causes internes et externes se complètent ; le mot étant le résultat d'un impact, d'une pression de l'histoire sur le système. [Guiraud 1986: 18]

That Old English, the language reflecting the culture of Anglo-Saxon England, is a central element in the theory here to be built up, I do not doubt for a moment. Commenting above on the large proportion in the core list of nouns of Germanic origin (about 67\%), I had already remarked that it could be no mere accident. My claim in what follows is that the morphological difference between ZP animal names and the other animal names is a clue to a difference in representation and categorization of animals that is deeply rooted in AS, not to say Germanic, culture. ${ }^{10}$

\section{A clue to a difference in representation and categorization}

\subsection{Where Anglo-Saxon culture comes in}

By analysing animal bone recovered from Anglo-Saxon settlements, archeologists have told us about the husbandry practices, kill-patterns and meat consumption habits of the Angles and the Saxons:

The evidence recovered from excavations emphasises that the landscape was fully utilised by the inhabitants of farms, or groups of farms, dispersed across the landscape. The extent of utilisation is exemplified by the settlement and cemetery excavated on a hilltop overlooking the English Channel at Bishopstone, Sussex (Bell, 1977). [...]. In the pastures stood sheep, cattle and a few horses and roaming more freely were geese, fowl and cats. [...] The food produced in this way [ref. mainly to crops of barley; my addition] was supplemented by marine resources: mussels, limpets and periwinkles gathered on the foreshore, conger eel from the lower shore and whiting taken from the sea; nets were made on the farm. The animals not only provided dairy products, meat, leather and wool for clothing; bone was used to make such things as combs, weaving tools and netting needles. In nearby woodland pigs were reared, and red and roe deer were hunted. [Arnold 1998: 33]

Though only part of the whole diet is visible archeologically, the picture is claimed to be fairly reliable - what little variation there was between settlements can be seen as the result of local environment, social or cultural differences, or is due to the recovery technique used in excavating [Arnold 1998: 33].

This picture of subsistence agriculture in AS England seems to lend some weight to Leach's argument [1964: 44] that the inhabitants of today's England see their animals as belonging to one of four categories:

\footnotetext{
10 The problem here is that there exists no written trace of the languages historically preceding $\mathrm{OE}$, namely Proto- and West Germanic, and the kind of conceptualization I want to focus on has to be supported by linguistic evidence. Like Anna Wierzbicka, "I am not saying that linguistic evidence is the only reliable guide to human conceptualization in general and to human categorization in particular. There are, of course, many other types of ethnographic evidence that anthropologists have traditionally relied on. But linguistic evidence is particularly revealing." [Wierzbicka 1996: 358].
} 
- those which are closest to human beings (house animals, or pets), and as such are always inedible;

- those which are tame but not very close (farm animals); they are not edible in sexually intact form, but only if castrated or immature;

- fields animals, or game, toward which human beings are alternatively friendly and hostile: game animals live under human protection but are killed at special seasons of the year, in accordance with set hunting rituals, being edible in sexually intact form.

- remote wild animals, which are not subject to human control and not edible.

As an anthropologist, Leach establishes a correspondence between the categories of edibility and those of sexual accessibility, noting that modern anthropology has accumulated comparative data pointing to a universal tendency to make ritual and verbal associations between eating and sexual intercourse. The correspondence between people and animals can thus be summed up (summary based on Leach [1964: 44]):

$\begin{array}{lll}\begin{array}{l}\text { Kin (incest prohibition) } \\ \text { Kin but not very close parents } \\ \text { (marriage prohibition sometimes } \\ \text { coupled with premarital sex relations) }\end{array} & \leftrightarrow & \begin{array}{l}\text { Pet animals (not edible) } \\ \text { Farm animals } \\ \text { Strangers, neighbours, etc. } \\ \text { (marriage alliance, }\end{array} \\ \begin{array}{l}\text { (castration coupled with edibility) } \\ \text { friend/enemy ambiguity) }\end{array} & \begin{array}{l}\text { Game animals } \\ \text { (edible in sexually intact form) } \\ \text { (alternation between friendship \& } \\ \text { Remote strangers } \\ \text { (no sex relations) }\end{array} & \begin{array}{l}\text { Remote wild animals } \\ \text { (not edible) }\end{array}\end{array}$

Leach claims that some animals are the focus of ritual attitudes, implying taboo, while others are not. The occurrence of taboo is indicated not only by associations of the sort just described, but also by the various types and intensities of killing and eating restrictions, by ritual performance, or again by such linguistic evidence as verbal abuse, the intrusion of euphemism, etc.

In that respect game animals form an intermediate or ambiguous category of protected/killed creatures which is heavily taboo-loaded:

- They are normally protected for part of the year (like pet and farm animals) and killed at set seasons (like wild animals), in accordance with set hunting rituals.

- $\quad$ Although fox is not a ZP animal name, the linguistic aspects of fox-hunting give us a good idea of how taboo-loaded the game-hunting ritual can be. Foxes are hunted by packs of dogs and, at the end of the ritual killing, the fox's head and tail are cut off, to be preserved as trophies. None of this may be expressed in plain language: the fox is spoken of as a $d o g$, the dogs themselves being referred to as hounds, the fox's head as a mask, the tail as a brush, and it is considered highly improper to use any other words. "The intensity of feeling aroused by these performances almost baffles the imagination. [...] We find, for example, as commonly occurs in other societies in analogous contexts, that the sacredness of the situation is marked by language inversions, the use of special terms for familiar objects, and so on." [Leach 1964: 52]

- Game animals are usually edible and when eaten, they are in sexually intact form. 
- They are culturally associated with the people who are not kin but neighbours, friends or even potential enemies, a category in which one ordinarily expects to find a partner.

My theory is that the PDE category of ZP animal names is a reflection of the psychological salience of game animals in Anglo-Saxon culture, originating not only in their being considered a source of food, but also in their being the focus of ritual attitudes, as explained. Put differently, the marking of plural in these nouns is a linguistic trace of the long-standing cultural status of their referents as a taboo-loaded category of animals.

We observed in §1.5.1 that, apart from sheep and swine, the names in the core list represent birds, fishes and ruminant mammals of the deer family. It is interesting to relate this to a suggestion by Carola Hicks that the three creatures, birds, fish and stag, depicted on the Lullingstone bowl ${ }^{11}$ may be symbolic of the three elements of air, water and earth [Hicks 1993: 28-9]. No explanation is given for this attribution, but Speake, another art historian working on AS animal art, independently observes that "the symbolic significance of the three creatures [bird, boar and serpent] may also relate to the elements they inhabit. As an inhabitant of the sky the bird is appropriate as a solar symbol; the boar as an inhabitant of the earth would be appropriate linked to an earth deity." [Speake 1980: 92]. Another scholarly interpretation is that the animals on the Lullingstone bowl, especially the birds, "refer to the activities of hunting and hawking, well-established pastimes among the Germanic Anglo-Saxon warrior-class, and could therefore be regarded as symbols of social status" [Hawkes 1997: 320; see also Hicks 1993: 26-29, 69-70]. The two interpretations are not contradictory. Being made independently by historians of art not concerned with linguistic questions, they seem to lend weight to my own view (as summarized above in bold type).

In the light of that theory, resistance to analogy takes on a new dimension. Generalisation of the $-s$ plural marker was already under way by late OE [McMahon 1994: 71-72], at a time when game animals such as stag and boar were still taxa of special significance in the culture of AS England. Cultural importance implies frequency of use by speakers, and "[i]n general, the connection of resistance to analogy with frequency seems to hold" [McMahon 1994: 73].

\subsection{Constitution of the contemporary category of ZP animal names}

From the ME period on, the lexical category of ZP animal names gradually built up. There are probably two ways in which the category developed.

First, the logical extension of the category became larger. Loan-words from OF, and later from Italian, Latin, Congolese, Narragansett, etc., provided that their signified corresponded to the semantic description "game animal", were aggregated into the original category, in accordance with Guiraud's concept of matrix [1986: 18]. The following example will illustrate the kind of logical extension I have in mind, springbok being a loan-word from Cape Dutch. Incidentally, it would be difficult to find a clearer literary description of game animals as an ambiguous (i.e. alternately protected and killed), hence taboo-loaded and almost sacred, category of animals:

11 The Lullingstone bowl is a hanging bowl of AS manufacture (late $7^{\text {th }}$ or early $8^{\text {th }}$ c.) on exhibition in the British Museum. 
(35) On the broad acres of my father's high-veld estate we had immense herds of springbok. Unlike many of our neighbours, my father and his grandfather before him had preserved the indigenous game on their land with the greatest care and affection. There was hardly a view from the high-raised stoep stretching all round our white house, which did not show a group of springbok peacefully grazing in the distance. [...] In summer when the distances were set on fire by the sun, when grass, bushes and sequinned savannahs were reflected in the quicksilver air in an endless succession of crackling coloured flames, the springbok held their position in the centre of the tumult with pastel delicacy and precision. [...]

But in the autumn the herds would contract, drawing young and old together in a circle the centre of which turned on their fear of death implicit in the coming winter. All differences among them vanished. Steadily they gave the homesteads an even wider berth, and became acutely wary of our movements as if they sensed that our season of killing, too, was about to begin. (The Seed and the Sower: 84-85)

The logical comprehension of the category evolved too. I believe this aspect to be much more recent and less important from a historical point of view. "Game" is a concept which implies a relationship between animals and human beings as hunters or catchers). According to the Cambridge International Dictionary of English, another (extralinguistic) relationship, that between animals and human beings as scientists or nature lovers, is subject to the same (linguistic) treatment. They give the following example:

(36) Ngorongoro Crater is a wildlife range for wildebeest, gazelle and zebra. (CIDE: 1086)

Is some analogy at work here, if only unconsciously, between animals as prey for hunters and animals as prey for harmless observers? Safari is now defined as an expedition for hunting or observing wild animals: "a journey; a cross-country expedition, often lasting days or weeks, orig. in E. Africa and on foot, especially for hunting; now often with motorized vehicles, for tourism, adventure, or scientific investigation" (OED, s.v. safari).

I would like to add a quotation from an American guide which is illustrative of the ambiguous status of some animals as game or objects of observation:

(37) Radio-tracking is being used to study the behavior of Mountain Lions in Florida, and an office has been established to investigate reports of sightings in the southern Appalachians. [...] Currently it [i.e. the Mountain Lion] is fully protected where rare (such as the eastern U.S.) and classified as a game animal where abundant." (NAM: 794)

In this paragraph, I focused on the development of the lexical category of ZP animal names, but it should be kept in mind that as a cultural construct it is naturally a fuzzy category with a constant influx and outflux of items:

(38) At some point we stopped eating squirrels in this country. Certainly the very first Americans ate them in abundance, as did the first European settlers, who cleared the ancient forests and issued bounties on the rodent plagues that ravaged their crops; in colonial Pennsylvania authorities offered hunters three pence per squirrel killed. [...] 
But somewhere along the way, squirrel declined in popularity as a game animal, replaced by bigger quarry, such as deer and turkey, whose numbers had grown in the countryside as the number of humans dwindled. Mainstream views on squirrel eating began to drift toward disdainful-it became something hillbillies and rednecks did.

(http://www.chicagoreader.com (article posted on August 16, 2012))

\subsection{The animal world as represented by the English language today}

Morphological treatment of animal names in PDE, with respect to number, reflects how reality is organized into culturally agreed-upon sections.

\begin{tabular}{|l|l|l|}
\hline \multicolumn{1}{|c|}{ Animals as food } & \multicolumn{1}{|c|}{ Animals as game } & \multicolumn{1}{|c|}{$\begin{array}{l}\text { Animals as fellow } \\
\text { creatures }\end{array}$} \\
\hline $\begin{array}{l}\text { uncount use } \\
\text { invariable forms }\end{array}$ & $\begin{array}{l}\text { count use } \\
\text { count } \text {-s plural suffix }\end{array}$ \\
\hline cf. (39) below - s plural suffixes & cf. (41) below \\
\hline $\begin{array}{l}\text { All } 3 \text { examples are from the same source: http://www.chicagoreader.com (article posted on } \\
\text { August 16, 2012) }\end{array}$ \\
\hline
\end{tabular}

(39) In Chicago in 1879, among the broiled sandpipers and black bear hams on the multispecies menu of the Grand Pacific Hotel's 24th annual Great Game Dinner, there were four preparations of squirrel, including black, gray, and an ornamental "Fox Squirrel in Arbor."

(40) a- I'd been awake since before dawn, creeping around the woods with 19-yearold Forrest Turner, a horse trainer and aspiring agriculture student who'd grown up hunting squirrels, turkey, and deer in these woods. He'd already shot about 15 to 20 squirrels since the season started.

b- (below a photograph, in the same article) Forrest Turner, 19, grew up hunting squirrel, turkey and deer in Southern Indiana

(41) City squirrels, faced with a relatively scarcer supply of tree nuts, supplement with the bounty of gardens and bird feeders, or scavenge what we cast away. They're rats with good $P R$, as the saying goes.

Rats at least know fear. City squirrels, on the other hand, know that the municipal code prevents you from drawing a bead on them with a muzzle loader.

\section{Conclusions}

\subsection{Multicausality}

ZP animal names form a class of nouns that resisted the powerful tide of regularisation in ME (i.e. extension of the plural suffix $-s$ ), was transmitted down to the present day, and in the process even developed by going against the historical trend. For most animal names, I believe this to have been the case because the animals in question were considered as game, a highly salient cultural category in AS, not to say Germanic, culture, a taboo-loaded category which was (still is?) the focus of ritual attitudes. This I refer to as cause no.1, in view of its importance.

Yet a few animal names stand out as not being accounted for by this theory. These include a) 3 nouns referring to farm animals, namely horse, sheep and swine (if we leave 
out neat, now obsolete and replaced by cattle); b) greenfly and hookworm, which are names for insects; c) osprey, which unlike the other ZP bird names does not refer to a game bird but to a predatory bird. I have put forward a tentative explanation of b) and c) in Toupin [2003], to which I refer the interested reader. For lack of space I now focus on the nouns in a).

They are still in current use in PDE, but horse can hardly be said to be a zero plural any longer. Plural horse, according to the OED, was in general use till the $17^{\text {th }} \mathrm{c}$. and is still frequent dialectically; but horses is found as early as the $13^{\text {th }} \mathrm{c}$. (evidence of this in Layamon), and its use increased till in the $17^{\text {th }} \mathrm{c}$. it became the regular plural in literary language.

Considering that in ME the 3 nouns were still zero plurals, I would like to underline a morphological change that occurred precisely during that period, namely the loss of the genitive plural inflection which was the rule in $\mathrm{OE}$ for any noun following a numeral: thus OE twentig horsa "twenty horses » $(-a$ being the genitive plural suffix for such neuter nouns as hors, sceap and swin) would have gradually reduced to ME twenty horse (with -e representing first an audible schwa but then becoming a "mute" vowel). ${ }^{12}$ Now, it seems sensible to say that the 3 farm animals in question, especially horse and sheep that often graze freely, were likely to be often counted by the people in charge of them. So, in the case of these animals, it may well be that retention of the original $\mathrm{OE}\langle\emptyset\rangle$ plural suffix was helped along by the loss of the genitive plural inflection in everyday phrases involving a numeral. ${ }^{13}$ This I call cause no.2; incidentally, it might also account for the retention of plural horse in military language meaning « horse soldiers ».

Turning to the fact that horse eventually filtered out of the class of zero plurals, I find extra support here for cause no.1, because horses were never considered typically edible animals in England. Archeologists tell us that in AS rural England horseflesh was less commonly eaten than in earlier periods and on contemporary settlements on the Continent. Horses' late killing age indicates that they were used for riding and as packanimals rather than for meat [Arnold 1998: 35]. This characteristic sets them in sharp contrast to sheep and swine, which were, alongside cattle, the commonest and economically most important farm animals, both an important source of food [Lapidge 1999: 39]. If indeed [ \pm edibility], as connected with rituals and taboos, is a crucial factor that determined how animals were categorized in AS culture, then these observations lend further support to my main theory.

Cause no.3: as already mentioned, $10 \mathrm{ZP}$ animal names can be singled out which are non-native and whose contemporary and/or etymological base forms end in [s] or [z], viz. crayfish, grouse, hippopotamus, luce, lynx, moose, partridge, plaice, rhinoceros and walrus. The final sibilant probably caused these words to be misinterpreted as plural, their foreign origin further confusing morphological analysis.

Some non-native animal names without a base-form ending in [s/z] can also be used in the plural without the regular $-s$ inflection. This is the case when the foreign plural form is borrowed and used as such in the English sentence (e.g. ndanko below, clearly the plural form of adanko in a Ghanaian language I haven't been able to identify):

(42) In my grandfather's time the forest was thick thick and higher; we didn't have to go far to kill a hog. Ah, their spoor began at the edge of the village and the taste

\footnotetext{
12 What happened to the genitive plural marker is but one aspect of the decay of the whole inflectional system that took place in the ME period [Barber 1993: 157-160].

${ }^{13}$ I am indebted here to Professor Gachelin (p.c.), who mentioned the possible importance and frequency of $<$ numeral+noun $>$ phrases in ME where farm animals are concerned.
} 
of boar meat was like water to us, we ate so much. I remember well. Now they have gone deep deep, the boar. [...] The smallest catch I have ever brought home is adanko. (Ndanko are not hard to catch. Even when they hide, their ears stick up so you can see them. If I created them I would have put their eyes on their pointed ears to keep them safe, but then I wouldn't be able to catch them. Maybe hunger would consume me. Ah, ndanko. They are fast, but I have many traps. That is a hunter's life.) (Tail of the Blue Bird)

It must be underlined that non-nativeness and oral form would probably have been insignificant in the face of regularisation if another major factor had not chanced to be at work in the history of English - the formation of the lexical category of ZP animal names.

\subsection{ZP animal names and the traditional description of English nouns}

English nouns are traditionally described as falling into 3 classes: count, uncount and proper nouns, to which French linguists usually add a fourth class, i.e. collective nouns [e.g. Larreya \& Rivière 2010: Chap.12]. Noun classes are established on the basis of 3 morphosyntactical criteria: a) alternation between singular and plural form, as indicated by the possibility of adding or removing a final $-s$; b) compatibility with some determiners (the indefinite article and certain quantifiers); c) verb agreement and number of a pronoun coreferent, if any. How do ZP animal names fit into that description?

a) Except for a handful of deer-type nouns, the exact list of which remains to be drawn, they can always add a final $-s$.

b) Regardless of the plural inflection they take, they are compatible with the determiners that cooccur with count nouns, viz. many, (a) few, and numerals (cf. (5) and (6)).

c) Regardless of their plural suffix, the following finite verb is in the plural, and so is a pronoun coreferent (cf. (15), (16), (32), (35), (42)).

It is therefore unnecessary to posit an extra class of nouns. ZP animal names are best accounted for as a subclass of count nouns. They do not belong to the class of collective nouns, thus rendering use of the word collective (e.g. OED, s.v. horse, 1.b, 3.b) somewhat misleading. Yet they do have something in common with collective nouns. If use of the $\emptyset$ plural suffix is not a constraint but a choice made by the speaker, what actually determines such a choice? My contention is that it reflects a difference in point of view: $\emptyset$ singles out one property of the referents (i.e. their being game animals), while $-s$ tends to present them as part of the larger animal world. This can be compared to verb agreement with collective nouns, where "The difference [singular vs. plural] reflects a difference in point of view" [Quirk et al. 1985: 316].

\subsection{ZP animal names and Culioli's speaker-centered theory}

The first link with Culioli's theory is obviously the concept of otherness (F. altérité). Otherness is a starting point in all things linguistic (F. L'altérité est de fondation) When otherness is taken into account and then eliminated, a process of identification takes place; when otherness is maintained, then differentiation is the case [Culioli 1990: 97].

The lexical category of ZP animal names implies a tension between identification with other animal names (as a result of analogy) and differentiation (as resistance to 
analogy). So far, the development of the category and its very existence point to differentiation having the upper hand.

Secondly, it seems to me that the concept of "notion" which is central in Culioli's theory is useful to address the question of ZP animal names. A notion can be defined as "a complex bundle of structured physico-cultural properties" [Bouscaren et al. 1992: 153154]. The notion involved here would be the complex notion /game animal/, represented in English sentences not only by the compound noun animal game, but also by the different common nouns referring to game animals in PDE.

A notional domain structures the class of occurrences of a given notion. It is endowed with an organizing centre, that is, a prototypical occurrence, which I suggest could be boar. Boar is a common gender noun, monosyllabic, of OE origin, it alternates between regular and zero plural, and refers to a game animal of edible quality. A notional domain is also endowed with an attracting centre, that is, an imaginary occurrence having the constituent properties of the notion in the highest possible degree. I suggest that the attracting centre of the domain could be woodcock. The woodcock is not a mere game bird whose flesh is eatable, it is highly esteemed as an article of food. A notional domain can be represented as comprising a gradient, from center outward, and thus includes occurrences closer to the boundary of the domain than to the organizing centre. With reference to the urban culture prevalent in Englishspeaking countries today, rhinoceros would be one such occurrence:

(43) Humans have been eating giant animals since Homo sapiens were a thing, still eat giant animals today, and will continue to eat giant animals in the future. Nothing is safe unless it is explicitly poisonous. [...] Everything is fair game, including the powerful rhinoceros. As long as rhinos exist, people will hunt them, just like we did to most other megafauna. We will also be eating them to the end of time.

http://myths-made-real.blogspot.fr (article posted on January 30, 2013)

Sheep are edible but not game, horses are usually neither one nor the other (but let's not forget how they are represented in The Misfits!), etc. Fringe variation is probably infinite too, thus making the theoretical concepts of "gradient" and of "notional boundary" all the more useful to deal with the issue of ZP animal names in PDE.

The concepts of "notional domain" and of "lexical category" belong to two different theories, and as such they shouldn't be confused. We have just seen that the analogy with notional domains could be most useful to deal with aspects of variation inherent in the question of ZP animal names (e.g. Is squirrel one such name in, say, present-day American English? If it is, how representative of the domain is it? Is it more or less typical than elk, for instance?). By contrast, a "lexical category" is not a set of occurrences of a notion but a set of words, and as we have seen the words in question display common features at the level both of the signifier and of the signified.

But most importantly, the concept of "lexical category" has a definite advantage over that of "notional domain": it does not oppose the synchronic study of a linguistic system to its history, or to the history of the speakers of the language; it does not separate a language from the material world of which it is part. ${ }^{14}$ In other words, it proves the "principle of immanence" [Lecercle 2002], so central in linguistics since structuralism, to be wrong. This principle is best summed up in the critique by Deleuze \& Guattari [1980]

\footnotetext{
${ }^{14}$ We have seen that for Guiraud external and internal causes complement one another (cf. §2).
} 
of "the four postulates of linguistics". What follows is the relevant passage concerning postulate no.2, translated into English by Jean-Jacques Lecercle:

There is an abstract machine of language that does not appeal to any "extrinsic" factor. [...] Langue conforms to the structuralist 'principle of immanence', it is causa sui, and as such any relations it has with the world are merely contingent - or rather, they do not fall under the scope of linguistics, but of some other, secondary science. Linguistics inhabits an ivory tower, and langue is immune to wordly influences. The advantage of such constitutive separation is that language is able to be 'informational and communicational'. [Lecercle 2002: 86-87]

The "principle of immanence" can be observed to be at work in most speaker-centered theories, including Culioli's: (i) the speaker is the mere origin of discourse and does not have a body, an unconscious, or a place in a historical conjecture; (ii) only standard forms of languages are studied; (iii) the relations of languages with the material world of which they are part fall outside the scope of such theories. The (accurate) description of speaker-centered theories in the "call for papers" for this issue (Lexis 9) testifies to socio-historical phenomena being excluded from the linguist's reflection:

These theories differ from other theories, in so far as they seek to analyse languages through attested utterances. As a result, they try to take into account the context of the utterances, the relationship between the speaker and the co-speaker, as well as the conversational data involved, in order to explain their form and how their interpretation is construed.

The French school of enunciation linguistics has little influence outside French-speaking countries, but I don't think this is the main problem. It may survive if it is able to do away with the conception of the speaker as the mere object of a calculus, and to construct an object which, although endowed with a form of immanence, is not separated from the material world of which it is part. This, in my opinion, is the most important challenge facing speaker-centered theories at present. Isn't it time Culioli's warning was taken literally:

Dit en une phrase, la linguistique sans diachronie et sans anthropologie culturelle se condamne à l'assoupissement théorique. [Culioli 1999: 7]

\section{Bibliography}

\section{- References in linguistics}

Adamczewski Henri \& Delmas Claude, 1982, Grammaire linguistique de l'anglais, Paris : Armand Colin.

BARBER Charles, 1993, The English Language: a Historical Introduction, Cambridge: Cambridge University Press.

Berlin Brent, 1992, Ethnobiological Classification: Principles of Categorization of Plants and Animals in Traditional Societies, Princeton: Princeton University Press.

BolingER Dwight, 1992, "About furniture and birds", Cognitive Linguistics, n³/1: 111117. 
BousCAREN Janine et al., 1992, Introduction to a Linguistic Grammar of English. An Utterer-centered Approach, Paris \& Gap: Ophrys.

Culioli Antoine, 1990, Pour une linguistique de l'énonciation : opérations et représentations (Tome 1), Paris \& Gap : Ophrys.

Culioli Antoine, 1999, Pour une linguistique de l'énonciation : formalisation et opérations de repérage. (Tome 2 ), Paris \& Gap : Ophrys.

Deleuze Gilles \& GuATTARI Félix, 1980, Mille Plateaux, Paris : éditions de Minuit.

GuIRAUD Pierre, 1986 [1967], Structures étymologiques du lexique français, Paris : Payot.

LARREYA Paul \& RIVIERE Claude, 2010, Grammaire explicative de l'anglais. Paris: Longman.

LEACH E. R., 1964, "Anthropological aspects of language: animal categories and verbal abuse", in Lenneberg E. (ed.), New Directions in the Study of Language, M.I.T. Press: 23-63.

LECERCLE Jean-Jacques, 2002, Deleuze and Language, New York: Palgrave Macmillan.

МсманоN April, 1994, Understanding Language Change, Cambridge: Cambridge University Press.

Mosse Fernand, 1945, Manuel de l'anglais de Moyen Âge, des origines au XIVème siècle (vol. I: vieil-anglais), Paris : Aubier-Montaigne.

QuIRK Randolph et al., 1985, A Comprehensive Grammar of the English Language, Edinburgh: Longman.

SAUER Hans, 1999, "Animal names in the Epinal-Erfurt Glossary", in ConRAD-O'BriaIN Helen et al. (eds.), Text and Gloss: Studies in Insular Learning and Literature presented to Joseph Donovan Pheifer, Dublin: Four Courts Press: 128-158.

ToupIN Fabienne, 2003, "Animal names in Contemporary English: what is the marking of plural a marker of?”, in STÉvAnovitch Colette \& TixiER René (eds.), La Surface et la profondeur : Mélanges offerts à Guy Bourquin à l'occasion de son $75^{e}$ anniversaire, Université de Nancy (collection Grendel 7): 25-53.

WAKELIN Martyn, 1977 [1972], English Dialects: an Introduction, London: Athlone Press.

WierzBicka Anna, 1992, "Furniture and birds: a reply to Dwight Bolinger", Cognitive Linguistics $\mathrm{n}^{\circ} 3 / 1$ : 119-123.

\section{- References concerning animals in Anglo-Saxon Culture}

Arnold C. J., 1988, An Archaeology of the Early Anglo-Saxon Kingdoms, London \& New York: Routledge.

BARNAUD Jean-François, 2001, Le Bestiaire vieil-anglais : étude et traduction de textes animaliers dans la poésie vieil-anglaise, Paris: Publications de l'A.M.A.E.S (Hors Série 7, 2 vols.).

Hicks Carola, 1993, Animals in Early Medieval Art, Edinburgh: Edinburgh University Press.

HaWkES Jane, 1997, “Symbolic Lives: the Visual Evidence”, in Hines John (ed.), The AngloSaxons from the Migration Period to the Eighth Century: an Ethnographic Perspective, Woodbridge: the Boydell Press (San Marino Studies in Historical Archaeoethnology 2): 311-344.

LAPIDGE Michael et al. (eds.), 1999, The Blackwell Encyclopaedia of Anglo-Saxon England, Oxford \& Malden (Mass.): Blackwell.

SPEAKE George, 1980, Anglo-Saxon Animal Art and its Germanic Background, Oxford: Clarendon Press. 


\section{- Dictionaries, Encyclopaedias and Reference Books}

Bosworth Joseph \& Toller T. Northcote, 1954 [1898]. An Anglo-Saxon Dictionary, Glasgow, New York, Toronto: Oxford University Press.

Hall J.R. Clark \& MeritT D., 1960 [1894], A Concise Anglo-Saxon Dictionary, Toronto, Buffalo, London: University of Toronto Press.

Onions C. T. (ed.), 1966, The Oxford Dictionary of English Etymology, Oxford \& New York: Oxford University Press.

Procter Paul (ed.), 1978, The Longman Dictionary of Contemporary English, Harlow \& London: Longman.

Procter Paul (ed.), 1995. Cambridge International Dictionary of English. Cambridge, New York, Melbourne: Cambridge University Press.

RoBERTS Jane, KaY Christian \& Grundy Lynne, 2000, A Thesaurus of Old English (2 vols.) (King's College London Medieval Studies 11), Amsterdam \& Atlanta: Editions Rodopi B.V.

\section{- Corpus}

\section{Fiction}

Animal Farm, George Orwell, Penguin Books, 1989 (first published 1945)

A Prayer for Owen Meany, John Irving, Ballantine Books, 1997 (first published 1989)

England, England, Julian Barnes, Pan Books, 1999 (first published 1998)

Tail of the Blue Bird, Nii Ayikwei Parkes, Jonathan Cape, 2009

The Seed and the Sower, Laurens van der Post, Penguin Books, 1973 (first published in 1963)

\section{Non-fiction and dictionaries}

CIDE: Cambridge International Dictionary of English, Cambridge University Press, 1995

LDCE: Longman Dictionary of Contemporary English, Pearson, 2009 (first published 1978)

OED: Oxford English Dictionary, Third edition online, Oxford University Press, 2000 FC: It's a Great Day to Be in Fort Collins! The Official Guide for Visitors, 2001

NAM: John O. Whitaker Jr., National Audubon Society Field Guide to North American Mammals, Alfred A. Knopf, 1996 (first published 1980)

RMNP: Rocky Mountain National Park Magazine, 2001

\section{Abbreviations}

$\begin{array}{ll}\mathrm{AF}=\text { Anglo-French } & \mathrm{MHG}=\text { Middle High German } \\ \mathrm{AS}=\text { Anglo-Saxon } & \mathrm{MLG}=\text { Middle Low German } \\ \mathrm{c}=\text { century } & \mathrm{MnE}=\text { Modern English } \\ \mathrm{PDE}=\text { Present-Day English } & \mathrm{OE}=\text { Old English } \\ \mathrm{Du}=\text { Dutch } & \mathrm{OF}=\text { Old French } \\ \mathrm{It} \quad \text { Italian } & \mathrm{ON}=\text { Old Norse } \\ \mathrm{L}=\quad \text { Latin } & \mathrm{Scn}=\text { Scandinavian } \\ \mathrm{ME}=\text { Middle English } & \mathrm{Sp}=\text { Spanish }\end{array}$




\section{Appendix: the extended list of zero-plural animal names in Present- Day English}

\begin{tabular}{|c|c|c|}
\hline Name & Translation & Etymology \\
\hline antelope & antilope & $\mathrm{OF}$ \\
\hline barking-deer & muntjac & $\mathrm{OE}$ \\
\hline bear & ours & $\mathrm{OE}$ \\
\hline bighorn & mouflon & OE or ON for horn (?); ON for big \\
\hline bison & bison & $\mathrm{L}$ \\
\hline boar & sanglier & $\mathrm{OE}$ \\
\hline bream & brème & $\mathrm{F}$ \\
\hline buffalo & buffle; (US) bison & It \\
\hline caribou & caribou & probably of native American origin \\
\hline carp & carpe & $\mathrm{OF}$ \\
\hline catfish & poisson-chat & $\mathrm{OE}$ and $\mathrm{ONF}$ \\
\hline $\operatorname{cod}$ & morue & of uncertain origin; word known only in English \\
\hline $\operatorname{coot}$ & foulque & LG word whose earlier history is unknown \\
\hline$c r a b$ & crabe & $\mathrm{OE}$ \\
\hline crake & râle & ON \\
\hline crayfish & $\begin{array}{l}\text { écrevisse [eau douce] } \\
\text { langouste [eau salée] }\end{array}$ & $\mathrm{OF}$ \\
\hline deer & cerf & $\mathrm{OE}$ \\
\hline drake & canard (mâle) & West Germanic root of obscure origin \\
\hline duck & canard & $\mathrm{OE}$ \\
\hline elephant & elephant & $\mathrm{OF}$ \\
\hline $\begin{array}{l}\text { elk } \\
\text { evolution }\end{array}$ & élan & of obscure history; OE but not normal phonetic \\
\hline & & (maybe MHG?) \\
\hline fallow-deer & daim & $\mathrm{OE}$ \\
\hline fish & poisson & $\mathrm{OE}$ \\
\hline flounder & flet & $\mathrm{AF}$ \\
\hline fowl & oiseau, volatile & $\mathrm{OE}$ \\
\hline garfish & aiguille de mer, orphie & $\mathrm{OE}$ \\
\hline gazelle & gazelle & OF, of Arabic origin \\
\hline greenfly & puceron (vert) & $\mathrm{OE}$ \\
\hline grouse & grouse (coq de bruyère & e) of unknown origin: medieval L or Welsh \\
\hline halibut, holibut & flétan & of obscure origin but cognate with Swedish, G, Du words \\
\hline heron & héron & $\mathrm{OF}$ \\
\hline herring & hareng & $\mathrm{OE}$ \\
\hline hippopotamus & hippopotame & late $\mathrm{L}$ \\
\hline hookworm & ankylostome & $\mathrm{OE}$ \\
\hline horse & cheval & OE (plural horse still frequent dialectally for the animal) \\
\hline jackass-deer & singsing & $\mathrm{OE}$ for deer and ass; ME for jack \\
\hline lion & lion & $\mathrm{AF}$ \\
\hline luce & brochet & $\mathrm{OF}$ \\
\hline $\operatorname{lynx}$ & $\operatorname{lynx}$ & $\mathrm{L}$ \\
\hline mackerel & maquereau & OF but of unknown origin \\
\hline mallard & colvert & OF but of obscure origin \\
\hline moose & orignal & Narragansett (native American language) \\
\hline mountain lion & puma & $\mathrm{AF}$ for lion; $\mathrm{OF}$ for mountain \\
\hline
\end{tabular}


musk-deer porte-musc OE for deer; F for musk (ultimately of Persian origin) neat bœuf, vache, génisse $\mathrm{OE}$ 


\begin{tabular}{|c|c|c|}
\hline Name & Translation & Etymology \\
\hline neten & $\begin{array}{l}\text { animal du genre bœuf } \\
\text { ou cheval }\end{array}$ & $\mathrm{OE}$ \\
\hline osprey & balbuzard & L through an earlier OF noun \\
\hline partridge & perdrix & $\mathrm{OF}$ \\
\hline perch & perche & $\mathrm{F}$ \\
\hline pheasant & faisan & $\mathrm{AF}$ \\
\hline pike & brochet & perhaps $\mathrm{OE}$ \\
\hline plaice & carrelet, plie & $\mathrm{OF}$ \\
\hline plover & pluvier & $\mathrm{OF}$ \\
\hline quail & caille & $\mathrm{OF}$ \\
\hline red deer & cerf (commun) & $\mathrm{OE}$ \\
\hline reindeer & renne & $\mathrm{ON}$ \\
\hline reptile & reptile & late $\mathrm{L}$ \\
\hline rhinoceros & rhinocéros & late $\mathrm{L}$ \\
\hline sable & zibeline & OF \\
\hline salmon & saumon & $\mathrm{AF}$ \\
\hline seal & phoque & $\mathrm{OE}$ \\
\hline shad & alose & OE but of unknown origin \\
\hline sheep & mouton & $\mathrm{OE}$ \\
\hline shellfish & crustacés; coquillages & $\mathrm{OE}$ \\
\hline shrimp & crevette (grise) & obscurely related to $\mathrm{MHG}, \mathrm{MLG}, \mathrm{ON}$ \\
\hline silver-fish & argentine & $\mathrm{OE}$ \\
\hline skate & raie & $\mathrm{ON}$ \\
\hline snipe & bécassine & obscurely related to MLG, MDu, OHG; prob. of Scn origin \\
\hline sole & sole & $\mathrm{OF}$ \\
\hline springbok & springbok & Cape Du \\
\hline squirrel & écureuil & $\mathrm{OF}$ \\
\hline stag & cerf & $\mathrm{OE}$ \\
\hline starfish & étoile de mer & $\mathrm{OE}$ \\
\hline sturgeon & esturgeon & $\mathrm{AF}$ \\
\hline swine & porc & $\mathrm{OE}$ \\
\hline teal & sarcelle & ME pointing to an unrecorded OE $n$. \\
\hline tench & tanche & $\mathrm{OF}$ \\
\hline tiger & tigre & $\mathrm{OF}$ \\
\hline trout & truite & $\mathrm{OE}$ \\
\hline tuna & thon & Sp American; perhaps related to $\mathrm{L}$ \\
\hline turbot & turbot & $\mathrm{OF}$ \\
\hline walrus & morse & $\mathrm{Du}$ \\
\hline wildebeest & gnou & South-African Du \\
\hline woodcock & bécasse & $\mathrm{OE}$ \\
\hline zebra & zèbre & F, It, Sp or Portuguese, of Congolese origin \\
\hline
\end{tabular}

85 items 


\section{Methodological problems encountered in establishing the extended list, together with provisional answers in italics (January 2014)} neten)?

What should be done with obsolete zero-plural nouns yet attested in MnE (e.g.

I chose to count them in.

Is only Standard English to be taken into consideration? What with dialectal forms like widge? To strike them off is not satisfying, when they are so numerous; but to include them raises the problem of the amount of data available in written form.

I stuck to Standard English and disregarded purely dialectal forms like widge.

Some animals can be referred to by different names, for instance flounder/fluke, walrus/sea-horse/morse/rosmarine (the latter being obsolete). If three such synonyms all happen to be zero-plurals, should they constitute as many distinct entries in the list?

I think they should, because this is a linguistic count, based on linguistic criteria, regardless of how many different referents are involved.

Along the same lines, some animal names have a diminutive form (e.g. pickerel, diminutive of pike). If the diminutive of a ZP animal name is itself a zero-plural, should it constitute a distinct entry in the list?

I do not think it should; since a diminutive proper is derived from the same root as the non-diminutive form this would result in double count of the same etymological form.

Compounds having fish or deer as a second element are a real problem. For instance, is cod-fish to be counted in alongside cod? Cod is a ZP animal name, and so is cod-fish, but for a different reason: its second element, fish, head of the compound, is itself a ZP animal name.

In such cases, I adopted a somewhat complicated solution (I can see no other at the moment): I ignored compounds of the cod-fish type, taking only cod into consideration, but included those of the swordfish type (sword, as opposed to cod, is not a name for fish), together with those of the starfish type, that is, compounds that refer to animals that are not fish.

Deer, as we have seen, designates the family Cervidae and just as the cod-fish is a kind of fish, the roe deer is a kind of deer (etc.). Again, should we have (and count) two separate entries for such names, one for roe and another for roe deer?

I applied here the same linguistic policy: I ignored compounds of the roe deer type (roe being a free morpheme with exactly the same meaning as roe deer), but included those of the musk deer type (musk not being a name for deer). Reindeer is a more thorny case: in $P D E$ the compound is much more usual than the simple name, which has however been attested in English ever since the OE period. The following is from the account of Norway obtained by Alfred from Ohthere:

He hæfde tamra deora unbebohtra syx hund. Pa deor hi hatað hranas; para wæron syx stælhranas. (c893, K. ÆLFRED Oros. I. i. 18) 
(He had six hundred of tame deer unbought. These deer they call reins; six of these were decoy-reindeers.)

Some animal names occur only once in the PDE corpus as zero-plural forms; should these be counted in or not? It is easy to realize the consequence, in terms of count, of a high incidence of hapax legomena.

Precaution led me to include such names in the inventory. If other examples do not turn up in future investigation, it will be sensible to strike them off. For instance, my corpus contains only one instance of zebra and sable not adding -s in the plural (while wildebeest is rather well documented as a plural form):

Great herds of zebra, wildebeest, and sable, stood fearlessly gazing at us. (1929, REITZ Commando 129)

Here it could very well be that the expression "great herds of" is responsible for the form of the following nouns. Generally speaking, aspects of word-frequency will have to be held in mind and all hapax legomena, if there are any, will have to be identified. 